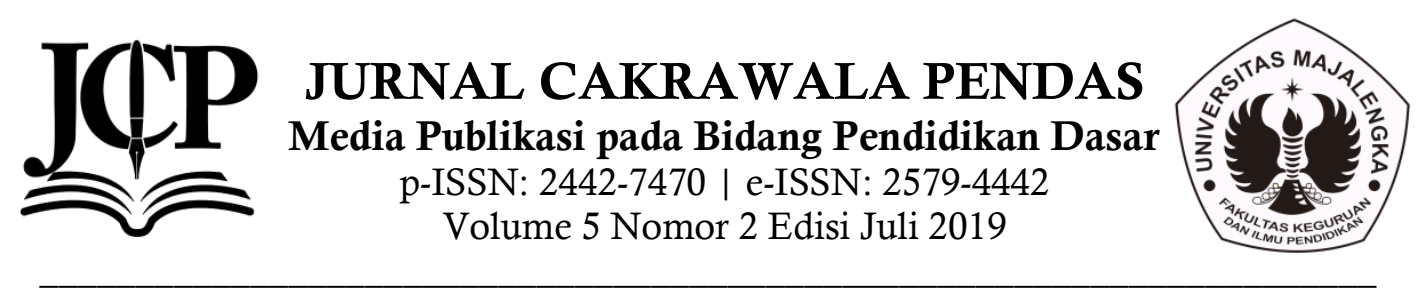

\title{
PENGEMBANGAN MEDIA BIG BOOK BELAJAR BERSAMA DODO DAN TEMAN-TEMAN UNTUK PEMBELAJARAN TEMATIK KELAS IV DI SEKOLAH DASAR
}

\author{
Arina Restian ${ }^{1}$, Suhesti Maslikah ${ }^{2}$ \\ 1,2 Universitas Muhammadiyah Malang \\ ${ }^{1}$ Email: Arina.poenya@gmail.com
}

\begin{abstract}
Abstrak
Penelitian ini bertujuan menghasilkan produk media Big Book belajar bersama Dodo dan teman-teman untuk pembelajaran tematik kelas IV di Sekolah Dasar yang memiliki tingkat kelayakan sebagai kriteria media untuk membantu siswa dalam proses pembelajaran tematik dikelas. Peneliti menggunakan pengembangan model ADDIE yang terdiri dari lima tahapan yaitu, Analyze, Design, Development, Implementation, Evaluation. Hasil penelitian ini menunjukkan bahwa pnggunaan media dapat membantu siswa dalam proses pembelajaran tematik dikelas. Peneliti melakukan validasi media Big Book melalui validasi ahli media, ahli materi, ahli bahasa, dan ahli pembelajaran hasilnya yaitu media dapat diuji coba sesuai saran dan komentar dari para ahli. Hal ini dibuktikan oleh hasil validasi beberapa ahli antara lain perolehan presentase validasi ahli media sebesar $96,6 \%$, perolehan presentase dari ahli materi sebesar 91,6\%, perolehan presentase dari ahli bahasa adalah $81,25 \%$, perolehan presentase dari ahli pembelajaran sebesar 93,3\%. Penggunaan media Big Book mendapatkan respon yang sangat baik terhadap pengguna yaitu dengan hasil angket respon siswa dengan presentase sebesar 96\% untuk uji coba kelompok kecil dan 96,25 untuk uji coba kelompok besar di SD Muhammadiyah 05 Batu. Hasil penelitian ini, media Big Book pembelajaran tematik disarankan dipergunakan untuk pembelajaran tematik kelas IV di Sekolah Dasar guna membantu siswa dan guru untuk mencapai tujuan pembelajaran dan menciptakan pembelajaran tematik yang menarik.
\end{abstract}

Kata Kunci: Media Big Book, Sekolah Dasar, Pembelajaran Tematik. 


\section{Pendahuluan}

Pemerintah sudah melakukan perubahan kurikulum yaitu Kurikulum 2013. Pembelajaran K13 atau yang dikenal dengan pembelajaran tematik. Pembelajaran Tematik adalah pembelajaran yang diawali dengan suatu tema tertentu yang mengaitkan dengan pokok bahasan lain, konsep tertentu dikaitkan dengan konsep lain yang dilakukan secara spontan atau direncanakan baik dalam satu bidang studi atau lebih dan dengan beragam pengalaman belajar sehingga pembelajaran menjadi semakin bermakna (Kadir, 2015:6).

Pembelajaran Tematik memiliki tujuan pembelajaran yaitu memudahkan pemusatan perhatian pada satu tema tertentu, anak didik mempelajari pengetahuan dan mengembangkan berbagai kompetensi dasar antar isi mata pelajaran dalam tema yang sama, pemahaman materi mata pelajaran lebih mendalam dan berkesan, komepetensi dasar dapat dikembangkan lebih baik dengan mengaitkan mata pelajaran lain dengan pengalaman pribadi siswa, lebih dapat dirasakan manfaat dan makna belajar karena materi disajikan dalam konteks tema yang jelas, siswa lebih bergairah belajar karena dapat berkomunikasi dalam situasi nyata, untuk mengembangkan suatu kemampuan dalam suatu mata pelajaran dan sekaligus dapat mempelajari mata pelajaran lain, guru dapat menghemat waktu sebab mata pelajaran yang disajikan secara tematik dapat dipersiapkan sekaligus, dan diberikan dalam dua atau tiga pertemuan, dan waktu selebihnya dapat dimanfaatkan untuk kegiatan remedial, pemantapan, atau pengayaan materi (Kadir, 2015:7).

Berdasarkan pengertian dari PP No. 19 Tahun 2005 Bab IV Pasal 19 ayat 1 bahwa pemerintah menyatakan bahwa, "Proses pembelajaran pada satuan pendidikan diselenggarakan secara interaktif, inspiratif, menyenangkan, menantang, memotivasi peserta didik untuk berpartisipasi aktif serta memberikan ruang yang cukup bagi prakarsa, kreativitas, dan kemandirian sesuai dengan bakat, minat, dan perkembangan fisik serta psikologis peserta didik." (Zulfahmi, 2013:278).
Analisis kegiatan yang dilakukan di kelas VI di SD Muhmmadiyah 05 Batu pada hari Senin, 5 November 2018, bahwa pada saat melaksanakan pembelajaran tematik dikelas sangat jarang menggunakan sebuah media pembelajaran untuk memudakan siswa dalam memahami setiap materi yang baru agar dapat dipahami oleh siswa serta dapat bertahan lama dalam memorinya, namun kurangnya penggunaan media dapat menghambat proses pelaksanaan pembelajaran tematik. Biasanya media pembelajaran yang digunakan hanya sebatas gambar yang ada di dalam buku, buku yang digunakan dalam pembelajaran juga hanya menggunakan buku tema saja. Siswa cenderung tidak aktif dan tidak bisa melaksanakan pembelajaran yang diharapkan. Selain hanya menggunakan media gambar, siswa terkadang menjadi lebih cepat bosan jika diminta untuk membaca materi pada buku siswa, guru terkadang juga masih merasa kesulitan dalam mengaitkan antar materi satu dengan yang lainnya, untuk metode pembelajaran yang digunakan guru yaitu ceramah dan penugasan sehingga membuat siswa menjadi lebih cepat bosan.

Berdasarkan pengamatan dan memahami kondisi yang ada di SD Muhammadiyah 05 Batu khususnya kelas 4 SD bahwa perlu adanya pengembangan media pembelajaran yang dapat menunjang pembelajaran tematik pada sekolah ini, dan mendukung proses pembelajaran agar lebih menyenangkan bagi siswa dan membuat siswa menjadi lebih aktif. Berdasarkan kondisi tersebut, sesuai dengan karaktr siswa kelas IV dengan umur 7-11 tahun bahwa mereka berada pada tahap operasional konkrit. Konkrit mengandung makna pada proses belajar dimulai dari hal yang konkrit yakni dapat dilihat, didengar, dibau, diraba, dan diotak-atik. Konkrit memiliki ciri yaitu seperti senang bermain beregu, memiliki rasa ingin tahu yang besar, mampu berikir sistematis, senang bermain dengan kelompok dan bergerak, maka hal yang perlu dilakukan agar dapat menumbuhkan semangat pada siswa dalam belajar dikelas yaitu dengan membuat sebuah media pembelajaran dikelas khususnya untuk pembelajaran tematik. 
Menurut Arsyad, (2013:19) pemakaian media pembelajaran dalam proses belajar mengajar dapat membangkitkan keinginan dan minat yang baru, membangkitkan motivasi dan rangsangan kegiatan belajar, dan bahkan membawa pengaruh-pengaruh psikologis bagi siswa. Cara lain agar siswa senang dalam belajar yaitu dengan membuat sebuah media pembelajaran yang dapat diotak-atik langsung oleh siswa, jadi siswa dapat bermain sambil belajar.

Pengembangan media yang dapat diotak-atik oleh siswa menjadi salah satu alternatif bagi siswa agar tertarik dalam belajar. Media Big Book tematik ini yaitu media dalam bentuk buku cerita bergambar dengan ukuran besar yang berisikan cerita dengan didukung gambar-gambar yang disusun sesuai alur cerita yang menarik sehingga membentuk jalinan cerita yang didalamnya juga terdapat soal-soal yang harus dikerjakan oleh siswa.

Soal-soal yang ada pada media Big Book ini dapat diotak-atik oleh siswa. Media ini juga memiliki beberapa keunggulan yaitu dapat dibawa kemana-mana, dapat menarik perhatian siswa dengan tampilannya yang menarik besar, berwarnawarni serta media ini bisa digunakan secara berkelompok maupun tidak berkelompok.

Media Big book tematik ini menggunakan cerita bertemakan kartun, karena dapat menumbuhkan minat baca untuk siswa. Berbeda dengan penyajian materi yang terdapat buku tematik, pada Big Book ini berisi gambar dan cerita. Penyajian materi yang diberikan, siswa tidak akan merasa berhadapan langsung dengan materi pelajaran seperti yang mereka lakukan dengan buku yang biasa mereka pelajari sebelumnya karena pada media Big Book ini materi dikemas dengan menarik yang ceritanya dalam kehidupan sehari-hari anak.

Pentingnya buku cerita disebutkan oleh Setiawati, (2013:132) bahwa pentingnya buku cerita dapat mengajak anak-anak untuk masuk dalam fantasi cerita. Cerita tersebut akan membuat anakanak tidak merasa jenuh dalam belajar tematik. Pada Big Book didalmnya bercerita tentang matri yang ada pada pembelajaran tematik Tema 6 Cita-citaku Subtema 1 Aku dan Cita-citaku Pembelajaran 1 yang didalamnya terdapat mata pelajaran Bahasa Indonesia yaitu puisi, IPA dengan materi pertumbuhan siklus pada hewan dan SBdP materi bernyanyi dengan memperhatikan tempo pada nada. Media ini terdapat cerita yang membuat siswa lebih mudah memahami materi tersebut.

Berdasarkan keunggulan dan cara penggunaan media tersebut, maka media Big Book ini diharapkan dapat meningkatkan proses pembelajaran khusunya untuk pembelajaran tematik tma 6 cita-citaku subtma 1 aku dan cita-citaku pembelajaran 1. Sehingga siswa bersemangat dalam melaksanakan pembelajaran dikelas dan dapat memotivasi siswa untuk melaksanakan pembelajaran dikelas.

Berdasarkan penjelasan ditas maka penelitian dengan judul "Pengembangan Media Big Book Belajar Bersama Dodo dan Teman-teman untuk Pembelajaran Tematik kelas IV di Sekolah Dasar" perlu segera dilakukan. Tujuan dari penelitian ini yaitu untuk mengetahui kelayakan produk media Big Book belajar bersama Dodo dan temanteman untuk pembelajaran tematik kelas IV di Sekolah Dasar.

\section{Kajian Pustaka}

1. Pembelajaran Tematik di Sekolah Dasar

Pembelajaran tematik adalah pembelajaran yang memadukan antara berbagai mata pelajaran atau bidang studi dengan menggunakan tema tertentu. Menurut Kadir, (2015:6) menyatakan bahwa Pembelajaran tematik adalah pembelajaran yang diawali dengan suatu tema tertentu yang mengaitkan dengan pokok bahasan lain, yang dilakukan secara spontan atau direncanakan baik dalam satu bidang studi atau lebih dan dengan beragam pengalaman belajar sehingga pembelajaran menjadi semakin bermakna.

Berdasarkan pernyataan di atas dapat disimpulkan bahwa pengertian tematik adalah suatu pembelajaran yang memadukan antara pelajaran bidang studi satu dengan pelajaran bidang studi yang lain, atau mengaitkan antara materi satu dengan materi yang lain sehingga siswa akan memperoleh pengetahuan dan 
keterampilan secara utuh sehingga pembelajaran menjadi lebih bermakna.

\section{Media Pembelajaran}

Media sering diartikan sebagai perantara komunikasi antara guru dan siswa demi terciptanya suatu pembelajaran yang efektif dan efisien. Media merupakan berbagai macam jenis komponen atau benda yang ada di lingkungan siswa guna menciptakan rangsangan belajar siswa menurut Gagne dalam (Sadiman, dkk, 2010:6). Menurut Miarso (2007:457) media merupakan salah satu perangsang bagi siswa agar pembelajaran dapat berlangsung. Media memberikan rangsangan bagi siswa untuk melaksanakan proses pembelajaran.

Pembelajaran merupakan segala sesuatu yang dapat menyalurkan pesan, dapat merangsang pikiran, perasaan, dan kemauan siswa sehingga dapat mendorong tercapainya proses belajar untuk menambah informasi baru pada diri siswa (Haryono, 2014:48).

Berdasarkan pendapat dari beberapa ahli mengenai media dan pembelajaran dapat disimpulkan bahwa media pembelajaran merupakan suatu perantara komunikasi bagi guru dan siswa berupa alat bantu guna menciptakan rangsangan belajar siswa. Oleh karena itu media pembelajaran dapat menentukan dan membentuk pengetahuan, keterampilan, dan sikap siswa. Media pembelajaran digunakan agar dapat mempermudah atau membantu guru dalam melaksanakan proses pembelajaran.

3. Media Big Book

Menurut USAID dalam Fitriana, (2017:552) media Big Book merupakan media yang mengkolaborasikan antara gambar dan teks yang didesain dengan besar baik ukuran teks, gambar, dan lainnya sehingga siswa dapat membaca secara bersama maupun terbimbing. Ukuran Big Book bisa beragam, misalnya A3,A4,A5, atau seukuran Koran.

Media pembelajaran Big Book ini didesain dengan ukuran yang besar mirip dengan ukuran kertas yaitu A3 yang berisikan cerita yang didukung gambargambar yang disusun sesuai alur cerita yang menarik sehingga membentuk jalinan cerita yang didalamnya terdapat soal-soal yang harus dikerjakan. Soal-soal tersebut disajikan dalam bentuk soal yang dapat diotak-atik oleh siswa. Konsep cerita yang ada pada media ini berisikan sebuah cerita anak sehari-hari.

\section{Metode Penelitian}

Model yang dikembagkan dalam penelitian ini menggunakan model ADDIE. Model pengembangan ini memiliki beberapa tahapan yang terdapat dalam Tegeh dkk, ( 2014:42) meliputi tahap analisis (analyze), desain (design), pengembangan (development), implementasi (implementation), evaluasi (avaluation). Model ADDIE memiliki kegiatan evaluasi terhadap aktivitas pengembangan pada setiap tahapan (Tegeh dkk, 2014:41).

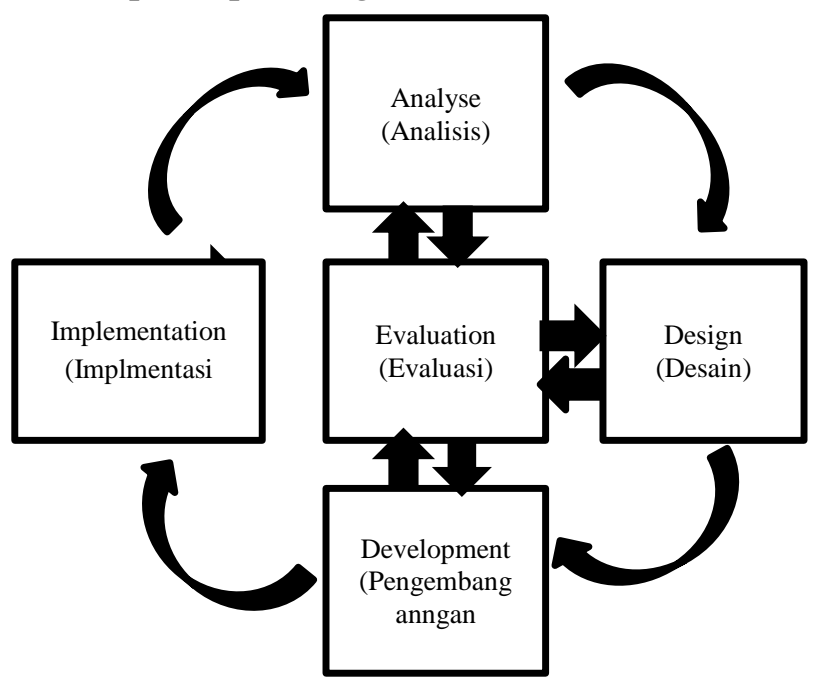

Gambar 1 Tahapan Pengembangan Model ADDIE

Hal tersebut dilakukan untuk mengurangi kesalahan atau kekurangan dalam pengembangan produk media. Langkah penelitian dan pengembangan ADDIE dalam penelitian ini jika disajikan dalam bentuk bagan adalah sebagai berikut.

\section{Hasil dan Pembahasan}

\section{Hasil Penelitian}

Hasil penelitian tentang pengembangan media Big Book belajar bersama Dodo dan temna-teman untuk pembelajaran tematik dilakukan penelitian di SD Muhammadiyah 05 Batu. Berikut merupakan penjelasan dari hasil penelitian yang telah dikembangkan.

1. Pengembangan Media Big Book belajar bersama Dodo dan teman-teman untuk pembelajaran tematik kelas IV di sekolah dasar 
a. Analyze (analisis)

Langkah awal kegiatan penelitian dan pengembangan yaitu melakukan analisis untuk mengetahui kebutuhan yang digunakan dalam proses pembelajaran yang dilakukan di kelas, serta menganalisis media yang digunakan pada pembelajaran tematik yang ada di kelas IV SD Muhammadiyah 05 Batu. Hasil analisis kebutuhan dari observasi yang dilakukan di SD Muhammadiyah 05 Batu pada tanggal 5 November 2018.

Dari hasil observasi dan wawancara tersebut mendapatkan hasil bahwa di SD tersebut membutuhkan media pembelajaran untuk menunjang proses pembelajaran dikelas, karena media yang digunakan masih mnggunakan media gambar, selain itu siswa juga kurang antusias jika diminta untuk membaca, metode yang digunakan hanya menggunakan metode ceramah dan penugasan. Guru juga masih mengalami kesulitan dalam mengkaitkan antar materi satu dengan materi yang lainnya.

b. Design (perencanaan)

Pada tahap desain, peneliti menentukan materi yang akan digunakan pada media dengan mencari KI dan KD yang ada pada buku guru dan buku siswa, kmudian menentukan isi cerita, kemdian merancang produk media Big Book yang didalamnya terdapat teks ceirta, gambar, dan soal yang dapat diotak-atik oleh siswa. Berikut rancangan media Big Book.

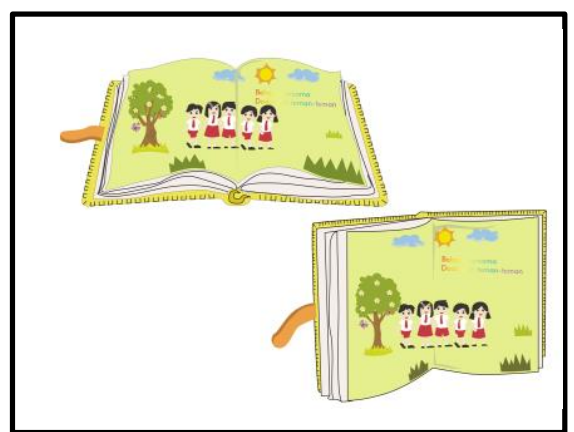

Gambar 2 Rancangan Media Big Book

Pada gambar diatas merupakan desain Big Book secara keseluruhan, media ini berukuran A3 dan terbuat dari kain katun dan kain flanel.

c. Development (pengembangan)

Tahap ini merupakan tindak lanjut dari tahap desain. Pada tahap ini kegiatan yang dilakukan yaitu mengembangkan desain yang dirancang kedalam bentuk fisik berupa produk. Tahap ini peneliti menggabungkan antara teks cerita, gambar, polyster, kain yang sudah dicetak, dan buku panduan ke dalam bentuk media Big Book yang sebenarnya. Produk yang telah dibuat kemudian akan divalidasi oleh para ahli yaitu ahli media, ahli materi, ahli Bahasa dan ahli pembelajaran agar peneliti dapat mengethaui kelayakan dan kelemahan produk media yang telah dikembangkan oleh peneliti.

1. Validasi Ahli Media Pembelajaran tahap pertama

Validasi yang dilihat dari ahli media dilihat dari aspek desain, pewarnaan, grafis, pemakaian kata atau Bahasa, dan kegunaan media dalam pembelajaran. Adapun hasil yang diperoleh dari validasi ahli media pembelajaran berdasarkan angket validator dapat diperoleh skor 55 dengan skor maksimal 60 dan menunjukkan presentase $91,6 \%$ sesudah revisi. Adapun rincian skor validator ahli media pembelajaran adalah sebagai berikut:

Tabel 1 Hasil Validator Ahli Media Sebelum revisi

\begin{tabular}{|c|c|c|c|}
\hline No & Indikator & $\begin{array}{c}\text { Skor } \\
\text { maksi } \\
\text { mal }\end{array}$ & $\begin{array}{l}\text { Skor } \\
\text { hasil }\end{array}$ \\
\hline 1. & $\begin{array}{l}\text { Kombinasi warna yang } \\
\text { digunakan dalam media }\end{array}$ & 4 & 3 \\
\hline 2. & $\begin{array}{l}\text { Warna yang digunakan } \\
\text { dalam media tidak } \\
\text { mengganggu materi }\end{array}$ & 4 & 3 \\
\hline 3. & Media aman digunakan & 4 & 4 \\
\hline 4. & Media tahan lama & 4 & 4 \\
\hline 5. & $\begin{array}{l}\text { Kesesuaian media } \\
\text { dengan lingkungan } \\
\text { belajar }\end{array}$ & 4 & 4 \\
\hline 6. & $\begin{array}{l}\text { Media mudah } \\
\text { dioperasikan }\end{array}$ & 4 & 4 \\
\hline 7. & $\begin{array}{l}\text { Tampilan gambar } \\
\text { menarik }\end{array}$ & 4 & 3 \\
\hline 8. & $\begin{array}{l}\text { Media dapat digunakan } \\
\text { sebagai alternative } \\
\text { pembelajaran }\end{array}$ & 4 & 3 \\
\hline 9. & $\begin{array}{l}\text { Keterkaitan gambar } \\
\text { dalam cerita dan materi } \\
\text { nyambung }\end{array}$ & 4 & 3 \\
\hline 10. & $\begin{array}{l}\text { Bahasa yang digunakan } \\
\text { mudah dipahami }\end{array}$ & 4 & 4 \\
\hline 11. & $\begin{array}{l}\text { Penyajian materi pada } \\
\text { mdedia jelas }\end{array}$ & 4 & 4 \\
\hline 12. & $\begin{array}{l}\text { Kemampuan media } \\
\text { dalam menarik } \\
\text { perhatian siswa }\end{array}$ & 4 & 4 \\
\hline 13. & $\begin{array}{l}\text { Kemampuan media } \\
\text { sebagai stimulus belajar }\end{array}$ & 4 & 4 \\
\hline
\end{tabular}




\begin{tabular}{lll}
\hline $14 . \quad \begin{array}{l}\text { Kemampuan media } \\
\text { dalam mengembangkan } \\
\text { motivasi siswa }\end{array}$ & 4 & 4 \\
\hline $15 . \quad \begin{array}{l}\text { Kesesuaian media } \\
\text { dengan sumber belajar }\end{array}$ & 4 & 4 \\
\hline Total & \multicolumn{2}{c}{55} \\
\hline Skor Maksimal & 60 \\
\hline Presentase & $91,6 \%$ \\
\hline
\end{tabular}

Hasil penelilaian ahli media pada tahap pertama memperoleh skor 55 dengan rata-rata 91,6\%. Berdasarkan pedoman konversi data kuantitatif ke kualitatif, media Big Book masuk dalam kriteria sangat layak digunakan.

2. Validasi Ahli Media tahap kedua

Data-data yang diperoleh dari ahli media pada tahap kedua berupa penilaian terhadap produk media pembelajaran yang dikembangkan kemudian diijadikan dasar penentuan kelayakan terhadap media. Komentar, kritik, dan saran yang diberikan ahli media juga menjadi dasar dalam melakukan revisi sehingga produk media pembelajaran benar-benar layak untuk dikembsngksn. Sehingga diharapkan adapeningkatan hasilyang diperoleh dari validasi pada tahap kedua ini.

Tabel 2 Hasil Skor Validator Ahli Media Sesudah Revisi

\begin{tabular}{clcc}
\hline No & \multicolumn{1}{c}{ Indikator } & $\begin{array}{c}\text { Skor } \\
\text { Maks } \\
\text { imal }\end{array}$ & $\begin{array}{c}\text { Skor } \\
\text { hasil }\end{array}$ \\
\hline 1. & $\begin{array}{l}\text { Kombinasi warna } \\
\text { yang digunakan } \\
\text { dalam media }\end{array}$ & 4 & 3 \\
\hline 2. & $\begin{array}{l}\text { Warna yang } \\
\text { digunakan dalam } \\
\text { media tidak } \\
\text { mengganggu materi }\end{array}$ & 4 & 4 \\
\hline 3. & $\begin{array}{l}\text { Media aman } \\
\text { digunakan }\end{array}$ & 4 & 4 \\
\hline 4. & $\begin{array}{l}\text { Media tahan lama } \\
\text { Kesesuaian media } \\
\text { dengan lingkungan } \\
\text { belajar }\end{array}$ & 4 & 4 \\
\hline 6. & $\begin{array}{l}\text { Media mudah } \\
\text { dioperasikan }\end{array}$ & 4 & 4 \\
\hline 7. & $\begin{array}{l}\text { Tampilan gambar } \\
\text { menarik }\end{array}$ & 4 & 4 \\
\hline 8. & $\begin{array}{l}\text { Media dapat } \\
\text { digunakan sebagai } \\
\text { alternative } \\
\text { pembelajaran }\end{array}$ & 4 & 4 \\
\hline 9. & $\begin{array}{l}\text { Keterkaitan gambar } \\
\text { dalam cerita dan } \\
\text { materi nyambung }\end{array}$ & 4 & 4 \\
\hline 10. & Bahasa yang & 4 & 4 \\
\hline & & & \\
\hline
\end{tabular}

\begin{tabular}{|c|c|c|c|}
\hline & \multicolumn{3}{|l|}{$\begin{array}{l}\text { digunakan mudah } \\
\text { dipahami }\end{array}$} \\
\hline 11. & $\begin{array}{l}\text { Penyajian materi pada } \\
\text { mdedia jelas }\end{array}$ & 4 & 4 \\
\hline 12. & $\begin{array}{l}\text { Kemampuan media } \\
\text { dalam menarik } \\
\text { perhatian siswa }\end{array}$ & 4 & 4 \\
\hline 13. & $\begin{array}{l}\text { Kemampuan media } \\
\text { sebagai stimulus } \\
\text { belajar }\end{array}$ & 4 & 4 \\
\hline 14. & $\begin{array}{l}\text { Kemampuan mdia } \\
\text { dalam } \\
\text { mengembangkan } \\
\text { motivasi siswa }\end{array}$ & 4 & 4 \\
\hline 15. & $\begin{array}{l}\text { Kesesuaian media } \\
\text { dengan sumber belajar }\end{array}$ & 4 & 4 \\
\hline Total & & & \\
\hline Skor I & aksimal & & \\
\hline Presen & & & \\
\hline
\end{tabular}

Hasil penilaian ahli media mendapatkan skor 58 dengan rata-rata $96,6 \%$. Berdasarkan pedoman konvensi data kuantitatif ke kualitatif, maka produk media pembelajaran yang dikembangkan termasuk dalam kategori sangat layak digunakan.

3. Validasi Ahli Materi tahap pertama

Validasi yang dilakukan oleh ahli materi dapat dilihat dari aspek penyajian, isi materi holistik, dan umpan balik. Adapun hasil yang diperoleh dari hasil validasi ahli materi pembelajaran mendapatkan skor 57 dengan skor maksimal 60 dan menunjukkan presentase 95\% akan tetapi pada validasi materi tahap prtama masih mengalami revisi pada kriteria indikator dan ada 2 aspek belum diisi. Adapun rincian skor validator ali matri bisadilihat dibawah ini.

Tabel 3 Hasil Skor Validator Ahli materi Sebelum Revisi

\begin{tabular}{clcc}
\hline No & \multicolumn{1}{c}{ Indikator } & $\begin{array}{c}\text { Skor } \\
\text { maks } \\
\text { imal }\end{array}$ & $\begin{array}{c}\text { Skor } \\
\text { hasil }\end{array}$ \\
\hline 1. & $\begin{array}{l}\text { Penyampaian materi } \\
\text { runtut dan ssuai } \\
\text { dengan tema }\end{array}$ & 4 & 4 \\
\hline 2. & $\begin{array}{l}\text { Terdapat LKS dan } \\
\text { soal evaluasi }\end{array}$ & 4 & 4 \\
\hline 3. & $\begin{array}{l}\text { Penyampaian materi } \\
\text { terdapat di awal } \\
\text { dalam pemanfaatan } \\
\text { media }\end{array}$ & 4 & 3 \\
\hline 4. & $\begin{array}{l}\text { Penyampaian materi } \\
\text { terdapat di inti dalam } \\
\text { pemanfaatan media }\end{array}$ & 4 & 4 \\
\hline
\end{tabular}




\begin{tabular}{|c|c|c|c|}
\hline 5. & $\begin{array}{l}\text { Penyampaian materi } \\
\text { terdapat di akhir } \\
\text { dalam pemanfaatan } \\
\text { media }\end{array}$ & 4 & 3 \\
\hline 6. & $\begin{array}{l}\text { Keseesaian matri } \\
\text { dengan tema }\end{array}$ & 4 & 4 \\
\hline 7. & $\begin{array}{l}\text { Ksesuaian materi } \\
\text { dengan KD }\end{array}$ & 4 & 4 \\
\hline 8. & $\begin{array}{l}\text { Kelengkapan materi } \\
\text { dalam pembelajaran }\end{array}$ & 4 & 4 \\
\hline 9. & $\begin{array}{l}\text { Materi sesuai dengan } \\
\text { kondisi lingkungan } \\
\text { siswa }\end{array}$ & 4 & 4 \\
\hline 10. & $\begin{array}{l}\text { Materi meliputi } \\
\text { ilustrasi }\end{array}$ & 4 & 4 \\
\hline 11. & $\begin{array}{l}\text { Materi yang disajikan } \\
\text { di dalam cerita terkait } \\
\text { antara materi yang } \\
\text { satu dengan materi } \\
\text { yang lainnya }\end{array}$ & 4 & 4 \\
\hline 12. & $\begin{array}{l}\text { Keterkaitan materi } \\
\text { yang disajikan sesuai } \\
\text { dengan kemampuan } \\
\text { pemahaman siswa }\end{array}$ & 4 & 4 \\
\hline 13. & $\begin{array}{l}\text { Penyampaian materi } \\
\text { terdapat di awal, inti } \\
\text { dan akhir } \\
\text { pembelajaran }\end{array}$ & 4 & 3 \\
\hline 14. & $\begin{array}{l}\text { Pengguna tidak bosan } \\
\text { saat menggunakan } \\
\text { media pembelajaran }\end{array}$ & 4 & - \\
\hline 15. & $\begin{array}{l}\text { Media mendorong } \\
\text { siswa menemukan } \\
\text { jawaban soal yang } \\
\text { tepat }\end{array}$ & 4 & - \\
\hline 16. & $\begin{array}{l}\text { Memberikan makna } \\
\text { atau pesan kepada } \\
\text { siswa dalam } \\
\text { kehidupan sehari-hari }\end{array}$ & 4 & 4 \\
\hline \multicolumn{2}{|c|}{ Total } & \multicolumn{2}{|c|}{60} \\
\hline \multicolumn{2}{|c|}{ Skor Maksimal } & \multicolumn{2}{|c|}{57} \\
\hline \multicolumn{2}{|c|}{ Presentase } & \multicolumn{2}{|c|}{$95 \%$} \\
\hline
\end{tabular}

Hasil penilaian ahli media mendapatkan skor 57 dengan rata-rata $95 \%$. Berdasarkan pedoman konvensi data kuantitatif kekualitatif, maka produk media pembelajaran yang dikembangkan termasuk dalam kategori sangat layak digunakan.

4. Validasi Ahli Materi tahap kedua

Data-data yang diperoleh dari ahli media pada tahap kedua berupa penilaian terhadap produk media pembelajaran yang dikembangkan kemudian diijadikan dasar penentuan kelayakan terhadap materi. Komentar, kritik, dan saran yang diberikan ahli media juga menjadi dasar dalam melakukan revisi materi dalam pembelajaran benar-benar layak untuk dikembangkan. Berikut hasil validasi materi tahap kedua,

Tabel.4 Hasil Validasi Ahli Materi Sesudah Revisi

\begin{tabular}{|c|c|c|c|}
\hline No & Indikator & $\begin{array}{l}\text { Skor } \\
\text { maks } \\
\text { imal }\end{array}$ & $\begin{array}{l}\text { Skor } \\
\text { hasil }\end{array}$ \\
\hline 1. & $\begin{array}{l}\text { Penyampaian materi } \\
\text { runtut dan ssuai } \\
\text { dengan tema }\end{array}$ & 4 & 4 \\
\hline 2. & $\begin{array}{l}\text { Terdapat LKS dan } \\
\text { soal evaluasi }\end{array}$ & 4 & 4 \\
\hline 3. & $\begin{array}{l}\text { Penyampaian materi } \\
\text { terdapat di awal } \\
\text { dalam pemanfaatan } \\
\text { media }\end{array}$ & 4 & 4 \\
\hline 4. & $\begin{array}{l}\text { Ksesuaian materi } \\
\text { dengan KI }\end{array}$ & 4 & 4 \\
\hline 5. & $\begin{array}{l}\text { Kesesuaian materi } \\
\text { dengan KD }\end{array}$ & 4 & 4 \\
\hline 6. & $\begin{array}{l}\text { Kelengkapan materi } \\
\text { dalam pembelajaran }\end{array}$ & 4 & 4 \\
\hline 7. & $\begin{array}{l}\text { Materi sesuai dengan } \\
\text { kondisi lingkungan } \\
\text { siswa }\end{array}$ & 4 & 4 \\
\hline 8. & $\begin{array}{l}\text { Materi meliputi } \\
\text { ilustrasi }\end{array}$ & 4 & 3 \\
\hline 9. & $\begin{array}{l}\text { Keterkaitan materi } \\
\text { yang disajikan sesuai } \\
\text { dnegan kmampuan } \\
\text { pemahaman siswa }\end{array}$ & 4 & 3 \\
\hline 10. & $\begin{array}{l}\text { Materi yang disajikan } \\
\text { di dalam cerita terkait } \\
\text { antara materi yang } \\
\text { satu dengan materi } \\
\text { yang lainnya }\end{array}$ & 4 & 4 \\
\hline 11. & $\begin{array}{l}\text { Penyampaian materi } \\
\text { terdapat diawal, inti } \\
\text { dan akhir } \\
\text { pembelajaran }\end{array}$ & 4 & 3 \\
\hline 12. & $\begin{array}{l}\text { Memberikan makna } \\
\text { atau pesan kepada } \\
\text { siswa dalam } \\
\text { kehidupan sehari-hari }\end{array}$ & 4 & 4 \\
\hline \multicolumn{2}{|l|}{ Skor } & \multicolumn{2}{|c|}{44} \\
\hline \multicolumn{2}{|c|}{ Skor Maksimal } & \multicolumn{2}{|c|}{48} \\
\hline \multicolumn{2}{|c|}{ Presentase } & \multicolumn{2}{|c|}{$91,6 \%$} \\
\hline
\end{tabular}

Hasil penilaian ahli media mendapatkan skor 44 dengan rata-rata 91,6\%. Berdasarkan pedoman konvensi data kuantitatif kekualitatif, maka produk media pembelajaran yang dikembangkan termasuk dalam kategori sangat layak digunakan.

5. Validasi Ahli Bahasa tahap pertama 
Validasi yang dilakukan oleh ahli materi dapat dilihat dari aspek lugas, komunikatif, dan kesesuaian dengan kaidah bahasa Indonesia. Adapun hasil yang diperoleh dari hasil validasi ahli materi pembelajaran mendapatkan skor 31 dengan skor maksimal 48 dan menunjukkan presentase $64,5 \%$. Berikut hasil validasi materi tahap pertama:

Tabel 5 Hasil Validasi tahap pertama

\begin{tabular}{|c|c|c|c|}
\hline No & Indikator & $\begin{array}{l}\text { Skor } \\
\text { maks } \\
\text { imal }\end{array}$ & $\begin{array}{l}\text { Skor } \\
\text { hasil }\end{array}$ \\
\hline 1. & $\begin{array}{l}\text { Ketepatan kalimat } \\
\text { yang digunakan ssuai } \\
\text { tata kalimat Bahasa } \\
\text { Indonesia }\end{array}$ & 4 & 3 \\
\hline 2. & $\begin{array}{l}\text { Pemilihan kalimat } \\
\text { sesuai dengan } \\
\text { karakteristik siswa } \\
\text { SD/MI }\end{array}$ & 4 & 3 \\
\hline 3. & $\begin{array}{l}\text { Pemilihan kata yang } \\
\text { sderhana }\end{array}$ & 4 & 3 \\
\hline 4. & $\begin{array}{l}\text { Kebakuan istilah } \\
\text { sesuai dengan KBBI }\end{array}$ & 4 & 2 \\
\hline 5. & $\begin{array}{l}\text { Ketepatan struktur } \\
\text { kalimat }\end{array}$ & 4 & 2 \\
\hline 6. & $\begin{array}{l}\text { Bahasa yang } \\
\text { digunakan mudah } \\
\text { dipahami oleh siswa }\end{array}$ & 4 & 3 \\
\hline 7. & $\begin{array}{l}\text { Kalimat yang } \\
\text { digunakan terdapat } \\
\text { informasi }\end{array}$ & 4 & 3 \\
\hline 8. & $\begin{array}{l}\text { Pemahaman terdapat } \\
\text { pesan atau informasi }\end{array}$ & 4 & 3 \\
\hline 9. & $\begin{array}{l}\text { Bahsa yang } \\
\text { digunakan santun } \\
\text { bagi siswa SD/MI }\end{array}$ & 4 & 3 \\
\hline 10. & $\begin{array}{l}\text { Kesesuaian Bahasa } \\
\text { dengan tingkat } \\
\text { berfikir siswa }\end{array}$ & 4 & 3 \\
\hline 11. & $\begin{array}{l}\text { Tata Bahasa mudah } \\
\text { dibaca dan dipahami } \\
\text { oleh siswa }\end{array}$ & 4 & 2 \\
\hline 12. & $\begin{array}{l}\text { Ketepatan ejaan yang } \\
\text { digunakan dalam } \\
\text { setiap kalimat }\end{array}$ & 4 & 2 \\
\hline \multicolumn{2}{|c|}{ Total } & \multicolumn{2}{|c|}{31} \\
\hline \multicolumn{2}{|c|}{ Skor Maksimal } & \multicolumn{2}{|c|}{48} \\
\hline \multicolumn{2}{|c|}{ Presntase } & \multicolumn{2}{|c|}{$64,5 \%$} \\
\hline
\end{tabular}

Hasil penilaian ahli Bahasa mendapatkan skor 31 dengan rata-rata $64,5 \%$. Berdasarkan pedoman konvensi data kuantitatif kekualitatif, maka Bahasa yang digunakan dalam media yang dikembangkan masuk kategori belum layak digunakan.

6. Validasi tahap kedua

Data-data yang diperoleh dari ahli media pada tahap kedua berupa penilaian terhadap produk media pembelajaran yang dikembangkan kemudian diijadikan dasar penentuan kelayakan terhadapbahasa yang digunakan pada media. Komentar, kritik, dan saran yang diberikan ahli media juga menjadi dasar dalam melakukan revisi bahasa dalam pada media benar-benar layak untuk dikembangkan. Berikut hasil validasi materi tahap kedua,

Tabel 6 Hasil Validasi Ahli Bahasa Sesudah Revisi

\begin{tabular}{cccc}
\hline No & Indikator & $\begin{array}{c}\text { Skor } \\
\text { maks } \\
\text { imal }\end{array}$ & $\begin{array}{c}\text { Skor } \\
\text { hasil }\end{array}$ \\
\hline 1. & Ketepatan kalimat yang & 4 & 3
\end{tabular}
digunakan ssuai tata kalimat Bahasa Indonesia

2. Pemilihan kalimat 43
sesuai dengan karakteristik siswa $\mathrm{SD} / \mathrm{MI}$

\begin{tabular}{|c|c|c|c|}
\hline 3. & $\begin{array}{l}\text { Pemilihan kata yang } \\
\text { sderhana }\end{array}$ & 4 & 4 \\
\hline 4. & $\begin{array}{l}\text { Kebakuan istilah sesuai } \\
\text { dengan KBBI }\end{array}$ & 4 & 4 \\
\hline 5. & $\begin{array}{l}\text { Ketepatan struktur } \\
\text { kalimat }\end{array}$ & 4 & 3 \\
\hline 6. & $\begin{array}{l}\text { Bahasa yang digunakan } \\
\text { mudah dipahami oleh } \\
\text { siswa }\end{array}$ & 4 & 3 \\
\hline 7. & $\begin{array}{l}\text { Kalimat yang } \\
\text { digunakan terdapat } \\
\text { informasi }\end{array}$ & 4 & 3 \\
\hline 8. & $\begin{array}{l}\text { Pemahaman terdapat } \\
\text { pesan atau informasi }\end{array}$ & 4 & 3 \\
\hline 9. & $\begin{array}{l}\text { Bahsa yang digunakan } \\
\text { santun bagi siswa } \\
\text { SD/MI }\end{array}$ & 4 & 3 \\
\hline 10. & $\begin{array}{l}\text { Kesesuaian Bahasa } \\
\text { dengan tingkat berfikir } \\
\text { siswa }\end{array}$ & 4 & 3 \\
\hline 11. & $\begin{array}{l}\text { Tata Bahasa mudah } \\
\text { dibaca dan dipahami } \\
\text { oleh siswa }\end{array}$ & 4 & 4 \\
\hline 12. & $\begin{array}{l}\text { Ketepatan ejaan yang } \\
\text { digunakan dalam setiap } \\
\text { kalimat }\end{array}$ & 4 & 4 \\
\hline \multicolumn{2}{|c|}{ Total } & \multicolumn{2}{|c|}{38} \\
\hline \multicolumn{2}{|c|}{ Skor Maksimal } & \multicolumn{2}{|c|}{48} \\
\hline \multicolumn{2}{|c|}{ Presentase } & \multicolumn{2}{|c|}{81,25} \\
\hline
\end{tabular}


Hasil penilaian ahli Bahasa mendapatkan skor 38 dengan rata-rata $81,25 \%$. Berdasarkan pedoman konvensi data kuantitatif kekualitatif, maka produk media pembelajaran yang dikembangkan termasuk dalam kategori sangat layak digunakan.

7. Validai Ahli Pembelajaran

Validasi yang dilakukan oleh ahli pembelajaran dapat dilihat dari aspekefektivitas media saat digunakan, penyajian materi pada media, ketertarikan media pembelajaran. Adapun hasil yang diperoleh dari hasil validasi ahli pembelajaran mendapatkan skor 56 dengan skor maksimal 60 dan menunjukkan presentase $93,3 \%$. Berikut hasil validasi ahli pembelajaran

Tabel 7 Hasil Validasi ahli pembelajaran

\begin{tabular}{|c|c|c|c|}
\hline No & Indikator & $\begin{array}{l}\text { Skor } \\
\text { maks } \\
\text { imal }\end{array}$ & $\begin{array}{l}\text { Skor } \\
\text { hasil }\end{array}$ \\
\hline 1. & $\begin{array}{l}\text { Media mudah } \\
\text { dipahami }\end{array}$ & 4 & 4 \\
\hline 2. & Media aman bagi siswa & 4 & 4 \\
\hline 3. & Media tahan lama & 4 & 3 \\
\hline 4. & Media mudah dibawa & 4 & 4 \\
\hline 5. & $\begin{array}{l}\text { Media dapat } \\
\text { dipindahkan }\end{array}$ & 4 & 4 \\
\hline 6. & $\begin{array}{l}\text { Media dapat } \\
\text { membantu guru dalam } \\
\text { menyampaikan materi }\end{array}$ & 4 & 3 \\
\hline 7. & $\begin{array}{l}\text { Kemampuan me11.dia } \\
\text { sebagai alat bantu } \\
\text { pencapaian kompetensi } \\
\text { dasar }\end{array}$ & 4 & 3 \\
\hline 8. & $\begin{array}{l}\text { Kemampuan media } \\
\text { sebagai alat bantu } \\
\text { pencapaian indikator } \\
\text { dan tujuan } \\
\text { pembelajaran }\end{array}$ & 4 & 3 \\
\hline 9. & $\begin{array}{l}\text { Materi mudah } \\
\text { dipahami oleh siswa }\end{array}$ & 4 & 4 \\
\hline 10. & $\begin{array}{l}\text { Mdia dapat digunakan } \\
\text { ntuk menyelesaikan } \\
\text { soal yang ada pada } \\
\text { media Big Book }\end{array}$ & 4 & 4 \\
\hline 11. & $\begin{array}{l}\text { Media yang } \\
\text { dikembangkan dapat } \\
\text { digunakan } \\
\text { sebagaialernatif } \\
\text { pembelajaran }\end{array}$ & 4 & 4 \\
\hline 12. & $\begin{array}{l}\text { Keterarikan siswa } \\
\text { belajar dengan media } \\
\text { yang dikembangkan }\end{array}$ & 4 & 4 \\
\hline 13. & $\begin{array}{l}\text { Kemampuan media } \\
\text { menciptakan rasa }\end{array}$ & 4 & 4 \\
\hline
\end{tabular}

\begin{tabular}{|c|c|c|c|}
\hline \multicolumn{4}{|c|}{ semangat siswa } \\
\hline 14. & $\begin{array}{l}\text { Kemampuan media } \\
\text { dalam memicu } \\
\text { kreativitas peserta didik }\end{array}$ & 4 & 4 \\
\hline 15 . & $\begin{array}{l}\text { Kemampuan media } \\
\text { mengaktifkan siswa } \\
\text { dalam pembelajaran }\end{array}$ & 4 & 4 \\
\hline Total & & & \\
\hline Skor & Maksimal & & \\
\hline Prese & ntase & & \\
\hline
\end{tabular}

Hasil penilaian ahli pembelajaran mendapatkan skor 56 dengan rata-rata 93,3\%. Berdasarkan pedoman konvensi data kuantitatif ke kualitatif, maka pembelajaran yang digunakan dalam media yang dikembangkan masuk kategori sangat layak digunakan.

d. Implementatiton (Implementasi)

Tahap implmentasi merupakan tindak lanjut dari tahap pengembangan. Pada tahap implementasi media Big Book yang dikembangkan dan akan diimplementasikan di sekolah dasar. Pada penelitian ini media Big Book di impementasikan di SD Muhammadiyah 05 Batu. Tahap implementasi dilakukan pada 15 siswa kelas IV di SD Muhammadiyah 05 Bumiaji Kota Batu mulai tanggal 14 Februari sampai tanggal 18 Februari 2019. Peneliti menggunakan uji coba kelompok kecil dan uji coba kelompok besar. Berikut adalah hasil uji coba media:

Tabel 8 Hasil Uji Coba Media

\begin{tabular}{ccccc}
\hline No & Uji Coba & $\begin{array}{c}\text { Tot } \\
\text { al }\end{array}$ & $\begin{array}{c}\text { Skor } \\
\text { Maksim } \\
\text { al } \\
\text { Keseluru } \\
\text { han }\end{array}$ & $\begin{array}{c}\text { Present } \\
\text { ase }\end{array}$ \\
\hline 1. & $\begin{array}{c}\text { Kelompok } \\
\text { Kecil }\end{array}$ & 48 & 50 & $96 \%$ \\
\hline 2. & $\begin{array}{c}\text { Kelompok } \\
\text { Besar }\end{array}$ & 77 & 80 & $96,25 \%$ \\
\hline
\end{tabular}

1. Uji coba kelompok kecil

Uji coba kelompok kecil dilaksanakan pada tanggal 14 Februari 2019 dengan jumlah 5 siswa. Hasil respon siswa terhadap media saat implementasi ujicoba kelompok kecil diketahui bahwa media mendapatkan respon positif dari pengguna dengan ditunjukkan presentase skor positif (Ya) yakni 96\%. Jika dikonversikan pada skala guttman masuk dalam kategori baik sekali. Uji coba kelompok kecil dilakukan 
oleh peneiti sebagai masukan sebelum dilakukan pada skala besar.

2. Hasil uji coba kelompok besar

Ujicoba kelompok kecil dilaksakan padatanggal 15 Februari 2019 dengan jumlah 13 siswa. Hasil respon siswa terhadap media saat implementasi ujioba kelompok besar diketahui bahwa media mendapatkan respon positif dari pengguna dengan ditunjukkan presentase skor positif (Ya) yakni 96,6\%. Jika dikonversikan pada skala guttman masuk dalam kategori baik sekali.

\section{Pembahasan}

Pengembangan Media Big Book Belajar Bersama Dodo dan teman-teman untuk Pembelajaran Tematik Kelas IV di Sekolah Dasar

\section{a. Analyze (Analisis)}

Pada tahap ini, peneliti melakukan analisis di SD Muhammadiyah 05 Batu. Analisis digunakan agar peneliti mengetahui kondisi nyata yang ada dilapangan dan menegtahui kebutuhan yang harus dipenuhi disekolah serta mengetahui apa saja karakteristik siswa kelas IV di sekolah dasar.

Berdasarkan hasil wawancara dan observasi yang dilakukan oleh peneliti di SD Muhammadiyah 05 Batu bahwa untuk pembelajaran tematik yang dilakukan dikelas masih memerlukan media pembelajaran yang dapat menunjang proses pembelajaran siswa, siswa juga kurang antusias jika diminta untuk membaca, guru masih kesulitan dalam mengaitkan antara materi satu dengan materi yang lainnya, metode yang digunakan menggunakan metode ceramah atau teacher center, minimnya media yang disediakan sekolah serta belum pernah dikembangkannya media yang dapat berperan aktif dalam pembelajaran.

Berdasarkan hasil analisis tersebut peneliti menyimpulkan bahwa di SD Muhammadiyah 05 Batu khususnya untuk kelas IV SD memerlukan media pembelajaran yang dapat menunjang dalam proses pembelajaran siswa. Berdasarkan analisis kebutuhan, peneliti mengembangkan media Big Book belajar bersama Dodo dan teman-teman untuk pembelajaran tematik, dalam pembuatan sebuah media pembelajaran juga harus memperhatikan alat dan bahan yang digunakan agar tidak membahayakan bagi siswa SD serta dapat menumbuhkan semangat siswa dalam belajar.

Hal tersebut sejalan dengan pendapat Arsyad, (2013:74) bahwa krieria dalam pemilihan media bersumber pada konsep yang merupakan bagian dari sistem instruksional secara keseluruhan salah satunya dengan memilih media yang dapat digunakan secara terus menerus, bertahan dalam jangka waktu yang lama, tentunya juga aman saat digunakan oleh siswa, agar membangkitkan semangat siswa dalam mengikuti proses pembelajaran juga harus memperhatikan media yang digunakan, bahwa pemakain media pembelajaran dalam proses belajar mengajar dapat membangkitkan keinginan dan minat yang baru, membangkitkan motivasi dan rangsangan kegiatan belajar, dan bahkan membawa pengaruh-pengaruh psikologis bagi siswa Arsyad, (2013:19).

b. Design (Desain)

Tahap design atau perencanaan peneliti merancang produk media tersebut mulai dari bentuk media, ukuran media sampai isi yang terdapat pada media tersebut. Dalam merancang media harus disesuaikan dengan pada tahap analisis kebutuhan yang telah dilaksanakan. Peneliti akan merancang media Big Book. Media Big $B o o k$ merupakan buku cerita dengan ukuran besar yang dikemas dengan menarik karena terdapat gambar kartun dan didalamnya terdapat soal yang dapat diotak atik oleh siswa yang sesuai dengan karakter siswa SD.

Hal ini sesuai dengan teori Piaget dalam Worowirasti, dkk (2018:18) bahwa siswa SD merupakan siswa yang berada dalam tahap perkembangan berpikir operasional konkrit. Konkrit mengandung makna proses belajar dimulai dari hal yang kongkrit yakni dapat dilihat, didengar, dibau, diraba, dan diotak-atik.

c. Development (Pengembangan)

Pada tahap ini peneliti menjadikan rancangan menjadi produk nyata yaitu media Big Book. Media yang dikembangkan oleh peneliti berisikan pembelajaran tematik Tema 6 cita-citaku subtema laku dan cita-citaku pembelajaran 1. Hal ini 
didukung dengan pendapat (Haryono, 2014:47) bahwa media adalah berbagai alat dan bahan yang bisa digunakan untuk membantu dalam penyampaian materi pembelajaran.

d. Implementation (Implementasi)

Tahap implementasi dilakukan penerapan media disekolah. Sebelum diimplmentasikan, media Big Book telah divalidasi kepada para ahli validasi. Stelah media divalidasi dan dikatakan valid maka tahap selanjutnya yaitu uji coba produk atau media yang telah dikembangkan oleh peneliti di sekolah dasar. Uji coba media Big Book dilakukan di SD Muhammadiyah 05 Batu.

Berdasarkan hasil yang didapatkan media Big Book menunjukkan bahwa media dapat digunakan siswa untuk membantu siswa dalam proses pembelajaran tematik dikelas hal tersebut sesuai dengan pendapat Haryono, (2015 : 53) bahwa media pembelajaran merupakan seperangkat benda atau alat yang dibuat dengan sengaja dan digunakan untuk menanamkan atau mengembangkan konsep-konsep materi.

e. Evaluation (evaluasi)

Tahap terakhir pada model pengembangan penelitian ini yaitu evaluasi. Evaluasi dilakukan peneliti disetiap tahapan. Hasil evaluasi yang dilakukan yaitu berbentuk deskriptif kualitatatif dan deskriptif kuantitatif.

\section{Simpulan}

Media dikatakan layak digunakan sebagai media karena dilihat dari skor pemerolehan nilai validasi oleh para ahli, mulai dari validasi ahli media, ahli materi, ahli Bahasa, ahli pembelajaran, dan angket respon siswa. Pemerolehan uji validasi media dengan nilai $96,6 \%$ mendapatkan keterangan valid, layak untuk uji coba tanpa revisi. Perolehan uji validasi materi mendapatkan nilai $91,3 \%$ dengan keterangan valid, layak diujicobakan seesuai dengan komentar dan saran. Perolehan uji validasi Bahasa mendapatkan nilai $81,25 \%$ mendapatkan keterangan valid, layak untuk uji coba tanpa revisi, perolehan uji validasi ahli pembelajaran mendapatkan nilai 93,3\% dengan keterangan valid, layak diujicobakan seesuai dengan komentar dan saran.
Implementasi dilakukan di SD Muhammadiyah 05 Batu yang berjumlah 15 siswa akan tetapi 2 siswa tidak masuk menjadi 13 siswa. Peneliti menggunakan 2 kali uji coba yaitu pemakaian uji coba kelompok kecil dan uji coba kelompok besar. Uji coba kelompok kecil dilakukan dengan jumlah 5 siswa, selama melakukan uji coba kelompok kecil, siswa antusias dan senang menggunakan mdia Big Book. Berdasarkan rspon siswa seluruh siswa tertarik dengan media Big Book. Perolehan presentase uji coba kelompok kecil adalah $96 \%$ dinyatakan sangat valid. Selanjutnya adalah uji coba kelompok besar melibatkan 13 siswa, kegiatan uji coba kelompok besar seluruh siswa merasa senang mengikuti kegiatan pembelajaran. Uji coba kelompok besar mendapatkan prsentase $96,25 \%$ dan dinyatakan sangat valid.

\section{Daftar Pustaka}

Arsyad, Azhar. 2013. Media Pembelajaran. Jakarta. PT Ragagrafindo Persada.

Fitriana. 2017. Peningkatan Minat Membaca Menggunakan Media Big Book Pada Siswa Kelas IIIB SD Negeri Jageran. Jurnal Pendidikan Guru Sekolah Dasar. Edisi 6.

Fristoni, Subagyo. 2013. Penggunaan Media Papan Flanel Untuk Meningkatkan Proses Pembelajaran Tematik Pada Siswa Sekolah Dasar.Universitas Negeri Surabaya. 01 Nomor 02.

Haryono, Ari Dwi. 2015. Metode praktis pengembangan sumber dan media pembelajaran. Malang: Genius dan Pustaka Inspiratif.

Kadir, Abd \& Asrohah Hanun. 2015. Pembelajaran Tematik. Depok: PT Rajagrafindo Persada.

Majid, Abdul. 2017. Pembelajaran Tematik Terpadu. Bandung: PT Remaja Rosdakarya.

Majid, Abdul. 2014. Startegi Pembelajaran. Bandung: PT Remaja Rosdakarya. 
Puspaningrum, Dwi Riska \& Gunansyah Ganes. 2015. Pengaruh Penggunaan Media Big Book Terhadap Kemampuan Literasi Informasi Siswa Sekolah Dasar. JPGSD. Volume 03 Nomor 02.

Tegeh, I Made dkk. 2014. Model Penelitian dan Pengembangan. Yogyakarta: Graha Ilmu

Worowirastri, Dyah dkk. 2018. Analisis Penggunaan Media Pembelajaran Tematik di SD Muhammadiyah 9 Kota Malang. Jurnal Inovasi Pembelajaran. Volume 4 Nomor 1.

Zulfahmi. 2013. Indikator Pembelajaran Aktif dalam Konteks Pengimplementasian Pendekatan Pembelajaran Aktfif, Kreatif, Afektif, dan Menyenangkan (Pakem). Jurnal Al-Ta'lim. Jilid 1 Nomor 4 